has justified to the full the appointment of a geologist to the staff of the Chief Engineer. His election to the chair of geology at Sheffield, while enabling him to return to the pursuit and teaching of pure science as a basic study, will enable him to continue to maintain and emphasize the value of geology to all civil engineering practice, as he has done to military engineering in its widest sense.

\section{Chair of Geology at Leeds: Prof. W. Q. Kennedy}

DR. W. Q. KENNEDy, who has been appointed to the chair of geology in the University of Leeds, is a senior geologist on the staff of the Geological Survey in Scotland. Before joining the Geological Survey in 1928, Kennedy studied under J. W. Gregory in Glasgow and under Niggli in Zurich. As a result of his Continental training, he became one of the first geologists in Britain to apply Fedorow and Sander 'universal stage' technique to the microscopic study of rocks, and early in his career published a translation of Chudoba's text-book on the determination of plagioclase feldspars by 'universal stage' methods. Kennedy has made notable contributions to geological research. In petrology he has dealt with pyrometasomatic ore-deposits, composite lava-flows, the parent magma of the British Tertiary Province and, in conjunction with Dr. E. M. Anderson, the origins of basaltic magma. His conception of volcanic and plutonic associations has been acclaimed as a fundamental contribution to petrogenetic theory. Perhaps his most notable work in Seotland is his study of the Great Glen Fault, which led him to infer a lateral shift of some 65 miles along this fracture and to discuss its tectonic and metamorphic implications. His official Survey work with Dr. J. E. Richey on the Moine and subMoine rocks of the Morar district has also produced notable results in Highland stratigraphy and tectonics.

Prior to the opening of the new Geological Museum in London in 1935, Kennedy spent a year or two in London preparing the ground-floor exhibits illustrating volcanicity and glaciology. During the War, he has been concerned with economic investigations on Scottish feldspar mica, iron-ore, oil-shale, mineral oil, natural gas and dolomite. His pre-war discovery of a valuable muscovite deposit in the Scottish Highlands has proved to be of national importance.

\section{University Development at Birmingham}

ThE University of Birmingham has launched an appeal for $£ 1,500,000$ for purposes of development, and promises of $£ 638,636$ have already been received. Outstanding items in the proposed scheme are $£ 100,000$ each for four additional halls of residence (three for men and one for women), $£ 200,000$ for a new library, $£ 170,000$ for new laboratories for mech. anical and electrical engineering, $£ 150,000$ for buildings at Edgbaston to house the Faculties of Arts, Commerce and Law, and central administration, and $£ 40,000$ each for the endowment of chairs of geography and electronics. In the words of the ViceChancellor, Dr. Raymond Priestley, "Men and women who must guide and control a great industrial people, and the experts who are to be the spear-point of scientific industry, are best educated within sight and sound of the factory and the market-place. We are moving forward into a world in which technical development will take place at an accelerating rate.
To equip ourselves for the competition we shall have to face in order to maintain our standard of living if not our very existence-in the post-war world involves mobilization of the skill and talent of the whole people, together with development of character, to put the programme through. We need to combine the best features of the older universities with the specialities of the new that are in closer touch with the industrial world. Given the will and the apparatus, there is nowhere that this could be done better than here in Birmingham."

\section{Industrial Ophthalmology}

The Institute of Ophthalmology, Royal Eye Hospital, St. George's Circus, London, S.E.1, proposes to devote a considerable proportion of its funds to industrial ophthalmology. In view of the absenee of any co-ordinated work in this field, it is felt that a national survey of workers, and of work already accomplished, is a necessary preliminary to the undertaking of research on any specific aspect of this very extensive subject. The Institute therefore invites those who have routine experience in any branch of industrial ophthalmology, or who have undertaken original work bearing upon it, to communicate with the Institute stating briefly their experience and defining the aspect of the work with which they are most familiar-medical supervision, safety, lighting, industrial psychology, etc. It is the Institute's policy to promote the investigation of industrial ophthalmic problems in the districts in which they arise. It is hoped that those replying to this request will be willing to co-operate in their own areas and in their special fields of interest and experience as the national scheme develops. This invitation is extended not only to individual workers, but also to research and other organizations concerned. The funds will be distributed on the recommendation of the Scientific Executive Committe in the form of grants for approved work. The Committee proposes, initially, to support, co-ordinate and publish work undertaken throughout Great Britain.

\section{Industrial Data in Britain}

Acconding to an article in the Board of Trade Journal of May 26, 1945, the Board of Trade is to undertake, through the regional research subcommittees formed as adjuncts to the Distribution of Industry Committees, the collection and assembly, on a continuing basis, of a wide range of factual data required for distribution of industry purposes covering every locality in Britain. In making such surveys the Board of Trade will make the fullest use of information on industry already accumulated by the supply Ministries and by the Ministries of Labour and Town and Country Planning. It is also intended to take the fullest advantage of local knowledge by consultation with non-official bodies, whether universities, local authorities or industrial groups. By these means the Board of Trade should be made conversant with the industrial problems of all parts of the country and equipped to provide the industrial world with an information service to help individual firms in making decisions on the location of new factories.

\section{Astronomical Observatory of Madrid}

THe Anuario for 1945 of the Madrid Observatory has been prepared on a plan similar to that of the preceding issues, with some slight modifications intro- 
duced in the year-book for 1944. Observations and records of solar activity during 1944 have continued, and the results, together with those made at the observatories of Valencia and Cartuja, have been sent to the International Bureau at Zurich. Time signals have been carried out, and photographs of comets and planets, occultations of stars by the moon and other notable phenomena have been included in the programme. Boletin Astronómico, 2, No. 10, contains the results of observations of sunspots and prominences in 1938 and the positions of a number of comets observed in 1941 and 1942, while Bol. Ast., 3, No. 1 contains the results of solar observations made in 1939 and 1940, including also those made during the latter year at Valencia. Repairs were started in the Observatory, those to the astrographic pavilion being completed, and the installation of the instrument and the new cupola to house it will allow the renewal of observations. At the end of the year-book there is an interesting section containing 72 pages with the title "El Sistema Galáctico", by José María Torroja Menéndez. This provides a very useful summary of our knowledge of the galaxy.

\section{Belgian Scientific Delegates in Britain}

A THIRD group of Belgian professors representing the Belgian Fondation Universitaire is now visiting Britain for a fortnight at the invitation of the British Council. They are visiting universities or research institutions in London, Reading, Oxford, Cambridge, Newcastle, Aberdeen, Edinburgh, Liverpool and Greenwich, and the I.C.I. works at Billingham. The delegates are: Prof. F. Van den Dungen, professor of analytical mechanics, University of Brussels ; Prof. A. Michotte van den Berck, professor of experimentary psychology, University of Louvain; Prof. A. Gratia, professor of bacteriology, University of Liège; Prof. J. A. H. Rodhain, director of the Institute of Tropical Medicine, Antwerp; Prof. E. J. M. P. Mertens, professor of industrial chemistry, University of Louvain.

\section{Cambridge Summer School in X-Ray}

\section{Crystallography}

A SUMMer school in X-ray crystallography will be held again this year in the Department of Mineralogy and Petrology, and in the Cavendish Laboratory, Cambridge, during the two weeks September 3-14. The school is conceived as a means of providing an introduction to the fundamental theory, methods and techniques of X-ray diffraction, so that those whose researches, whether in the universities or in industry, lie in the field of physics, chemistry, metallurgy, mineralogy or biology may be able to recognize in their own work the types of problem to which these methods may with advantage be applied. The greater part of the course will be devoted to practical work on the interpretation of the various types of X-ray photograph. For the last two days, however, alternative lectures and demonstrations will be offered in two sections. One section will include further steps, theoretical and practical, in the study of crystal structures, while in the other some applications of the earlier work of the course to metallurgical problems will be studied. A detailed syllabus and form of application for admission may be obtained from Mr. G. F. Hickson, secretary of the Board of Extra-Mural Studies, Stuart House, Cambridge, to whom the completed application form should be returned not later than June 23, 1945.

\section{Announcements}

THE following appointments in the Colonial Services have been made: W. J. Kinghorn, to be director of agriculture, Bermuda; Miss B. Y. Campbell, to be nutrition officer, Trinidad; T. A. Russell, director of agriculture, Bermuda, to be agricultural officer, Nigeria ; N. M. Wight, agricultural officer, Tanganyika, to be senior agricultural officer, Jamaica.

Ar the anniversary meeting of the Linnean Society of London held on May 24, the following were elected officers for the year 1945-46: President, Mr. A. D. Cotton; Treasurer, Colonel F. C. Stern; Secretaries, Dr. B. Barnes (botany) and Dr. Malcolm A. Smith (zoology); New Members of Council, Mr. A. H. G. Alston, Prof. T. A. Bennet-Clark, Dr. F. C. Fraser, Dr. H. S. Holden and Dr. S. M. Manton.

AT the annual general meeting of the Physical Society on May 23 the following were elected or reelected for 1945-46: President, Prof. D. Brunt; Vice-Presidents, Sir Edward Appleton, Prof. S. Chapman, Prof. H. T. Flint, Prof. N. F. Mott ; Hon. Secretaries, Mr. J. H. Awbery (Papers), Dr. W. Jevons (Business); Hon. Foreign Secretary, Prof. E. N. da C. Andrade; Hon. Treasurer, Dr. C. C. Paterson; Hon. Librarian, Prof. L. C. Martin; Council, Prof. J. D. Bernal, Dr. B. Chalmers, Dr. C. H. Collie, Mr. E. R. Davies, Prof. G. I. Finch, Dr. W. B. Mann, Mr. A. J. Philpot, Dr. D. Roaf, Prof. H. R. Robinson, Dr. H. Shaw, Dr. W. S. Stiles, Dr. W. D. Wright. The officers of the Colour Group for 1945-46 are : Chairman, Dr. R. K. Schofield; Secretary, Dr. W. D. Wright; and of the Optical Group, Chairman, Inst. Capt. T. Y. Baker; Secretary, Mr. E. W. H. Selwyn.

AT the annual general meeting of the Illuminating Engineering Society held on May 15 the following were elected officers for the forthcoming session: President, Mr. H. C. Weston; Vice-Presidents, Mr. Howard Long, Mr. H. E. Chasteney and Mr. J. M. Waldram; Hon. Treasurer, Mr. N. V. Everton; Hon. Secretary, Mr. J. S. Dow ; Members of Council, Mr. J. N. Aldington, Mr. M. G. Bennett, Dr. W. M. Hampton, Mr. A. G. Higgins, Mr. J. S. Preston, Mr. A. J. Pashler, Mr. E. B. Sawyer, Dr. W. S. Stiles and Dr. W. D. Wright.

AT the meeting of the Board of the Finney-Howell Research Foundation, Inc., on March 2, fellowships were renewed for the third year for Dr. Nelicia Maier; for the second year for Drs. Muriel Virginia Bradley and Margaret Aston Kelsall; and a new fellowship awarded to Dr. Elizabeth Cavert Miller, to work at the University of Wisconsin. Applications for fellow. ships for 1946 must be made to the Foundation, Medical and Chirurgical Faculty Building, 1211 Cathedral Street, Baltimore, Md., U.S.A., before December 1945.

The Leeds Branch of the Association of Scientific Workers will hold an open conference on "Science and Education" at the Philosophical Hall, City Museum, Leeds, on June 9, at 2.30 p.m. It is hoped to discuss the teaching of scientific method in elementary education, the comparative value of science and the humanities in general education, and curricula for specialist technicians. Sir Robert Watson-Watt will open the discussion and Dr. W. T. Astbury will preside. Tickets of admission (price 18 .) can be obtained from the honorary secretary of the Leeds Branch of the Association of Scientific Workers, 95 Holywell Lane, Glasshoughton, Castleford. 